\title{
Influence of two bulge loops on the stability of RNA duplexes
}

\author{
CLAIRE V. CROWTHER, LAURA E. JONES, JESSICA N. MORELLI, ERIC M. MASTROGIACOMO, \\ CLAIRE PORTERFIELD, JESSICA L. KENT, and MARTIN J. SERRA \\ Department of Chemistry, Allegheny College, Meadville, Pennsylvania 16335, USA
}

\begin{abstract}
Fifty-three RNA duplexes containing two single nucleotide bulge loops were optically melted in $1 \mathrm{M} \mathrm{NaCl}$ in order to determine the thermodynamic parameters $\Delta H^{\circ}, \Delta S^{\circ}, \Delta G_{37}^{\circ}$, and $T_{M}$ for each duplex. Because of the large number of possible combinations and lack of sequence effects observed previously, we limited our initial investigation to adenosine bulges, the most common naturally occurring bulge. For example, the following duplexes were investigated: 5'GGCAXYAGGC/3'CCG YX CCG, 5'GGCAXY GCC/ $3^{\prime}$ CCG YXACGG, and 5'GGC XYAGCC/3'CCGAYX CGG. The identity of XY (where XY are Watson-Crick base pairs) and the total number of base pairs in the terminal and central stems were varied. As observed for duplexes with a single bulge loop, the effect of the two bulge loops on duplex stability is primarily influenced by non-nearest neighbor interactions. In particular, the stability of the stems influences the destabilization of the duplex by the inserted bulge loops. The model proposed to predict the influence of multiple bulge loops on duplex stability suggests that the destabilization of each bulge is related to the stability of the adjacent stems. A database of RNA secondary structures was examined to determine the naturally occurring abundance of duplexes containing multiple bulge loops. Of the 2000 examples found in the database, over $65 \%$ of the two bulge loops occur within 3 base pairs of each other. A database of RNA three-dimensional structures was examined to determine the structure of duplexes containing two single nucleotide bulge loops. The structures of the bulge loops are described.
\end{abstract}

Keywords: bulge loops; secondary structure; thermodynamics

\section{INTRODUCTION}

RNAs are involved in a wide variety of biological activities. RNAs can function as catalysts, either alone or in conjunction with protein (Altman 1990; Cech 1990; Pace and Brown 1995; Scott 2007). Ribosomal RNA has a direct involvement in protein biosynthesis (Noller et al. 1992; Nissen et al. 2000). MicroRNAs are intermediates in the silencing of RNAs, used to target and destroy viral and other RNAs (Plasterk 2002); and siRNAs (small interfering RNA) are involved in the destruction of their RNA targets (Ahlquist 2002). More than a dozen classes of riboswitches, RNA sequences that respond to specific small molecule ligands ranging from amino acids to coenzymes, are known currently (Winkler et al. 2004; Roth and Breaker 2009). A new class of RNA has emerged recently: lncRNA (long noncoding RNA) has been shown to be involved in chromatin remodeling and subsequent epigenetic effects (Guttman et al. 2009; Rinn and Chang 2012). The realization that RNA molecules play an active role in processes of gene expression and are not merely passive structural components has sparked interest in determining the structure of these RNA molecules. In addition, many diseases are mediated through RNA intermediates. Retroviruses, such as the

Corresponding author: mserra@allegheny.edu

Article is online at http://www.rnajournal.org/cgi/doi/10.1261/rna.056168. 116.
AIDS virus, are RNA-protein complexes. Antisense therapy relies on the binding of synthetic oligonucleotides to RNA targets (Uhlman and Peyman 1990; Chan et al. 2006). Understanding the structure of RNAs will allow rational design for drug therapy.

The structure and stability of fully base-paired duplex regions of RNA have been extensively investigated (Turner et al. 1988; Xia et al. 2001; Chen et al. 2012). In order to develop the nearest-neighbor model, the thermodynamics of various single-stranded RNA motifs (helices, bulges, internal loops, hairpins, dangling ends, multibranch loops, etc.) are studied in short RNA oligonucleotides. Based partially on these thermodynamic parameters, an algorithm was developed to predict secondary structure from sequence, and it currently predicts $73 \%$ of known base pairs (Mathews et al. 1999). The accuracy of the prediction is based on the measured thermodynamics of the various motifs. However, to fully utilize the rapid accumulation of nucleic acid sequence information, further refinements in structure prediction are necessary (Mathews et al. 1999; Andronescu et al. 2007; Lu et al. 2009).

(C) 2017 Crowther et al. This article is distributed exclusively by the RNA Society for the first 12 months after the full-issue publication date (see http://rnajournal.cshlp.org/site/misc/terms.xhtml). After 12 months, it is available under a Creative Commons License (Attribution-NonCommercial 4.0 International), as described at http://creativecommons.org/licenses/ by-nc/4.0/. 
A bulge occurs when a duplex is interrupted by one or more unpaired nucleotides in one of the strands. Such motifs have been determined to be important in many biological processes including protein binding (Peattie et al. 1981; Wu and Uhlenbeck 1987; Harper and Logsdon 1991; Lilley 1995), intron splicing (Schmelzer and Schweyen 1986; Parker et al. 1987), feedback regulation (Climie and Friesen 1987), and tertiary folding (Woese and Gutell 1989).

Although their biological significance has been studied and they are one of the most common motifs in RNA secondary structure (Michel and Dujon 1983; Woese and Gutell 1989), relatively few studies have been done on the thermodynamics of single nucleotide bulges in RNA (Fink and Crothers 1972; Groebe and Uhlenbeck 1988; Longfellow et al. 1990; Znosko et al. 2002; Blose et al. 2007; McCann et al. 2011; Lim et al. 2012). This has resulted in a lack of thermodynamic characterization of single bulges, and no studies have looked at the influence of two bulge loops in an RNA duplex. This study examines the influence of two bulge loops on the stability of RNA duplex formation and develops a model to predict the free energy contribution for the insertion of two single nucleotide bulge loops into an RNA duplex. These results can be incorporated in secondary structure prediction programs to improve the prediction of RNA secondary structure.

\section{RESULTS}

In the database of RNA secondary structures, 20,292 single nucleotide bulge loops were found. Of these, $>10 \%$ (2250) are located within a duplex containing a second bulge loop. The definition of a duplex used here is two bulges separated by a stretch of canonical base pairs (including wobble pairs) and terminated by a least 1 base pair (bp) on each end of the helix beyond the bulges. These bulge loops were characterized by both the relative orientation ( $\mathrm{BB}$, two bulge loops on the same side of the duplex; $\mathrm{Bb}$, bulge loops on opposite strands with the second bulge $3^{\prime}$ of the first bulge; bB, bulge loops on opposite strands with the second bulge $5^{\prime}$ of the first bulge) (see Table 2 for example secondary structures) and position of the two bulge loops relative to each other. The results of this search are summarized in Table 1. Several represent highly conserved motifs, including position 926 (Escherichia coli numbering; helix 28) of the small ribosomal subunit RNA: bB separated by $3 \mathrm{bp}$. Many of the bulges were separated by only a few base pairs. In fact, there are very few single nucleotide bulges separated by more than $9 \mathrm{bp}$. This is partially a result of the fact that the average duplex in rRNA is only 7 nucleotides (nt) long.

To determine the influence of two bulge loops on duplex formation, we measured the thermodynamic parameters for duplex formation for the oligonucleotides listed in Table 2. We examined only Group I adenosine bulges because adenosine is the most prevalent bulged nucleotide (Gutell et al. 2000) and Group I bulges eliminate any positional ambiguity (Blose et al. 2007). Fifty-three oligonucleo-
TABLE 1. Number of base pairs separating two single-nucleotide bulge loops in RNA secondary structures

Number of base pairs between

\begin{tabular}{lrrr} 
the two bulge loops & BB & Bb & bB \\
\hline 1 & 28 & 19 & 167 \\
2 & 113 & 22 & 39 \\
3 & 111 & 51 & 779 \\
4 & 56 & 36 & 32 \\
5 & 278 & 12 & 28 \\
6 & 97 & 11 & 50 \\
7 & 145 & 5 & 81 \\
8 & 53 & 12 & 11 \\
9 & 0 & 2 & 3 \\
10 & 0 & 0 & 1 \\
11 & 1 & 0 & 1 \\
12 & 0 & 3 & 3 \\
13 & 0 & 0 & 0 \\
\hline
\end{tabular}

The RNA Strand database of RNA secondary structures (Andronescu et al. 2008) containing 4666 structures of which 2898 contained bulge loops was analyzed. The database was searched for single nucleotide bulge loops. A total of 20,292 bulge loops was identified of which 2250 were located in duplexes with two single nucleotide bulge loops.

tides were examined (18, BB; $15, \mathrm{Bb}$; and $20, \mathrm{bB})$. The oligonucleotides are listed based upon the orientation of the bulge loops relative to each other and then based upon the number of base pairs in the stem regions. Residues in bold are the proposed bulged nucleotides. Structural studies of the RNAs are beyond the scope of this study; however, in choosing sequences to be investigated, we did screen for alternate structural possibilities. For the non-self-complementary sequences, the individual strands were melted and showed no discernable transition.

The parameters are the average values derived from fits of the melt curves and from $T_{\mathrm{M}}^{-1}$ versus $\log \left(C_{\mathrm{t}} / 4\right)$ (non-selfcomplementary) or $\left(\mathrm{C}_{\mathrm{t}}\right)$ (self-complementary) plots. The parameters from the two methods agree within 15\% for most duplexes in Table 2, suggesting that the two-state model is a reasonable approximation for these transitions (Freier et al. 1986; Allawi and SantaLucia 1997).

The two exceptions are (CGGCACG) 2 and (CGAGCCG) $)_{2}$, which are relatively low melting duplexes with difficult to fit lower baselines. Although the enthalpy values derived from the melt data for these two oligomers differ by $>15 \%$, the free energy values are similar $(-6.1$ and $-5.8 ;-6.2$ and -6.0) for (CGGCACG) 2 and (CGAGCCG) $)_{2}$, respectively. These free energy values give reasonable values for the two oligomers so we have chosen to include them in our analysis. The average deviations in thermodynamic parameter values are $6.5 \%, 7.4 \%$, and $1.8 \%$ for $\Delta H^{\circ}, \Delta S^{\circ}$, and $\Delta G_{37}^{\circ}$, respectively.

The free energy contribution of each bulged nucleotide was calculated from the experimental data according to Equation 3 and presented in Table 3. As observed with a single bulge loop, insertion of multiple bulge loops into a duplex 
TABLE 2. Thermodynamic parameters for duplex formation of multiple single nucleotide bulges ${ }^{\mathrm{a}}$

\begin{tabular}{|c|c|c|c|c|c|c|c|c|}
\hline \multirow[b]{2}{*}{ Oligomers $^{c}$} & \multicolumn{4}{|c|}{$\mathrm{T}_{\mathrm{M}}^{-1}$ vs $\log \mathrm{C}_{\mathrm{T}}$ plots } & \multicolumn{4}{|c|}{ Average of curve fits } \\
\hline & $\begin{array}{c}-\Delta \mathrm{H}^{\circ} \\
(\mathrm{kcal} / \mathrm{mol})\end{array}$ & $\begin{array}{l}-\Delta \mathrm{S}^{\circ} \\
(\mathrm{eu})\end{array}$ & $\begin{array}{c}-\Delta \mathrm{G}_{37}^{\mathrm{O}} \\
(\mathrm{kcal} / \mathrm{mol})\end{array}$ & $\begin{array}{l}\mathrm{T}_{\mathrm{M}}{ }^{\mathrm{b}} \\
\left({ }^{\circ} \mathrm{C}\right)\end{array}$ & $\begin{array}{c}-\Delta \mathrm{H}^{\circ} \\
(\mathrm{kcal} / \mathrm{mol})\end{array}$ & $\begin{array}{c}-\Delta \mathrm{S}^{\circ} \\
(\mathrm{eu})\end{array}$ & $\begin{array}{c}-\Delta \mathrm{G}_{37}^{\mathrm{o}} \\
(\mathrm{kcal} / \mathrm{mol})\end{array}$ & $\begin{array}{l}T_{M}{ }^{b} \\
\left({ }^{\circ} \mathrm{C}\right)\end{array}$ \\
\hline BB & & & & & & & & \\
\hline $\begin{array}{l}\text { GAGUUCAG } \\
\text { C CAAG C }\end{array}$ & 59.1 & 174.5 & 4.9 & 29.1 & 58.7 & 173.3 & 4.9 & 29.0 \\
\hline $\begin{array}{l}\text { GAGCCGAG } \\
\text { C CGGC C }\end{array}$ & 68.8 & 191.1 & 9.5 & 51.0 & 66.7 & 184.4 & 9.5 & 51.4 \\
\hline $\begin{array}{l}\text { CACCGGCAC } \\
\text { G GGCCG G }\end{array}$ & 54.5 & 139.6 & 11.2 & 66.0 & 57.8 & 149.0 & 11.6 & 67.0 \\
\hline $\begin{array}{l}\text { GCAUGAUG } \\
\text { CG AC AC }\end{array}$ & 41.6 & 117.7 & 5.1 & 26.8 & 36.7 & 101.3 & 5.2 & 26.4 \\
\hline $\begin{array}{l}\text { GUAGGAGC } \\
\text { CA CC CG }\end{array}$ & 36.3 & 98.7 & 5.7 & 30.1 & 31.2 & 81.2 & 6.0 & 33.8 \\
\hline $\begin{array}{l}\text { GCAGUUCACG } \\
\text { CG CAAG GC }\end{array}$ & 47.9 & 134.2 & 6.3 & 35.5 & 51.7 & 146.6 & 6.3 & 35.4 \\
\hline $\begin{array}{l}\text { GCAGCCACG } \\
\text { CG CGG GC }\end{array}$ & 41.3 & 110.7 & 7.0 & 40.6 & 40.8 & 108.9 & 7.0 & 40.9 \\
\hline $\begin{array}{l}\text { GCAGCCGACG } \\
\text { CG CGGC GC }\end{array}$ & 61.2 & 167.0 & 9.4 & 52.2 & 66.9 & 184.7 & 9.6 & 51.9 \\
\hline $\begin{array}{l}\text { GCAUGCGUACG } \\
\text { CG ACGCA GC }\end{array}$ & 32.4 & 78.1 & 8.0 & 50.8 & 29.6 & 69.3 & 8.1 & 54.6 \\
\hline $\begin{array}{l}\text { GGCAGAGCG } \\
\text { CCG C CGC }\end{array}$ & 41.2 & 108.0 & 7.7 & 45.9 & 35.1 & 88.4 & 7.7 & 47.7 \\
\hline $\begin{array}{l}\text { GGCACAGCC } \\
\text { CCG G CGG }\end{array}$ & 45.3 & 120.0 & 8.1 & 47.9 & 48.5 & 130.4 & 8.1 & 47.1 \\
\hline $\begin{array}{l}\text { GGCAUUAGGC } \\
\text { CCG AA CCG }\end{array}$ & 53.6 & 151.6 & 6.6 & 37.1 & 61.1 & 177.0 & 6.3 & 36.0 \\
\hline $\begin{array}{l}\text { GGCAGCAGGC } \\
\text { CCG CG CCG }\end{array}$ & 50.6 & 136.5 & 8.3 & 48.0 & 45.9 & 121.5 & 8.3 & 49.2 \\
\hline $\begin{array}{l}\text { GGCAUAUAGGC } \\
\text { CCG AUA CCG }\end{array}$ & 54.2 & 152.4 & 7.0 & 39.4 & 53.7 & 150.6 & 7.0 & 39.7 \\
\hline $\begin{array}{l}\text { GGCAUUUAGGC } \\
\text { CCG AAA CCG }\end{array}$ & 41.6 & 111.1 & 7.1 & 41.4 & 41.1 & 109.0 & 7.3 & 42.7 \\
\hline $\begin{array}{l}\text { GGCAGGCAGGC } \\
\text { CCG CCG CCG }\end{array}$ & 66.7 & 179.0 & 11.2 & 60.1 & 61.0 & 161.6 & 10.9 & 60.9 \\
\hline $\begin{array}{l}\text { GGCAUUUUAGGC } \\
\text { CCG AAAA CCG }\end{array}$ & 35.5 & 92.8 & 6.7 & 38.5 & 37.4 & 98.3 & 6.9 & 40.1 \\
\hline $\begin{array}{l}\text { GGCAUAAUAGGC } \\
\text { CCG AUUA CCG }\end{array}$ & 61.5 & 174.5 & 7.4 & 41.4 & 62.6 & 178.1 & 7.3 & 40.9 \\
\hline $\begin{array}{l}\text { Bb } \\
\text { GAGUAC C } \\
\text { C CAUGAG }\end{array}$ & 35.6 & 96.6 & 5.6 & 36.4 & 39.9 & 111.6 & 5.4 & 34.6 \\
\hline $\begin{array}{l}\text { GAGGAACC G } \\
\text { C CCUUGGAC }\end{array}$ & 60.4 & 161.5 & 10.3 & 57.7 & 60.6 & 162.1 & 10.3 & 57.8 \\
\hline $\begin{array}{l}\text { CAGUCCAC G } \\
\text { G CAGGUGAC }\end{array}$ & 70.7 & 189.1 & 12.0 & 63.2 & 65.1 & 172.2 & 11.7 & 63.8 \\
\hline $\begin{array}{l}\text { CAGUGCAC Gd } \\
\text { G CACGUGAC }\end{array}$ & 64.8 & 174.0 & 10.8 & 63.6 & 65.6 & 176.2 & 10.9 & 64.0 \\
\hline
\end{tabular}


TABLE 2. Continued

\begin{tabular}{|c|c|c|c|c|c|c|c|c|}
\hline \multirow[b]{2}{*}{ Oligomers $^{c}$} & \multicolumn{4}{|c|}{$\mathrm{T}_{\mathrm{M}}{ }^{-1}$ vs $\log \mathrm{C}_{\mathrm{T}}$ plots } & \multicolumn{4}{|c|}{ Average of curve fits } \\
\hline & $\begin{array}{c}-\Delta \mathrm{H}^{\circ} \\
(\mathrm{kcal} / \mathrm{mol})\end{array}$ & $\begin{array}{c}-\Delta \mathrm{S}^{\circ} \\
(\mathrm{eu})\end{array}$ & $\begin{array}{c}-\Delta \mathrm{G}_{37}^{\mathrm{o}} \\
(\mathrm{kcal} / \mathrm{mol})\end{array}$ & $\begin{array}{l}\mathrm{T}_{\mathrm{M}}{ }^{\mathrm{b}} \\
\left({ }^{\circ} \mathrm{C}\right)\end{array}$ & $\begin{array}{c}-\Delta \mathrm{H}^{\circ} \\
(\mathrm{kcal} / \mathrm{mol})\end{array}$ & $\begin{array}{c}-\Delta \mathrm{S}^{\circ} \\
(\mathrm{eu})\end{array}$ & $\begin{array}{c}-\Delta \mathrm{G}_{37}^{\mathrm{o}} \\
(\mathrm{kcal} / \mathrm{mol})\end{array}$ & $\begin{array}{l}T_{M}{ }^{b} \\
\left({ }^{\circ} \mathrm{C}\right)\end{array}$ \\
\hline $\begin{array}{l}\text { CAGGUACC } \text { G }^{d} \\
\text { G CCAUGGAC }\end{array}$ & 67.0 & 179.8 & 11.3 & 65.2 & 67.8 & 181.8 & 11.4 & 65.4 \\
\hline $\begin{array}{l}\text { CGAGC CG } \\
\text { GC CGAGC }\end{array}$ & 17.8 & 37.8 & 6.1 & 44.4 & 28.1 & 71.9 & 5.8 & 38.9 \\
\hline $\begin{array}{l}\text { CGAUGA GC } \\
\text { GC ACUACG }\end{array}$ & 53.3 & 152.7 & 5.9 & 33.5 & 47.3 & 132.8 & 6.0 & 33.8 \\
\hline $\begin{array}{l}\text { CGAGUAC CG } \\
\text { GC CAUGAGC }\end{array}$ & 23.5 & 61.0 & 6.1 & 43.6 & 26.7 & 61.7 & 6.0 & 41.0 \\
\hline $\begin{array}{l}\text { GCAGGCC GC } \\
\text { CG CCGGACG }\end{array}$ & 59.3 & 158.3 & 10.2 & 62.5 & 50.4 & 131.0 & 9.8 & 64.6 \\
\hline $\begin{array}{l}\text { GCAUGCGCA GC } \\
\text { CG ACGCGUACG }\end{array}$ & 51.9 & 135.9 & 9.8 & 63.4 & 53.6 & 141.1 & 9.8 & 63.1 \\
\hline $\begin{array}{l}\text { GUGAGC C AC } \\
\text { CAC CGAG UG }\end{array}$ & 42.3 & 116.8 & 6.1 & 40.2 & 48.4 & 136.6 & 6.1 & 39.5 \\
\hline $\begin{array}{l}\text { GGCACG GCC } \\
\text { CCG GCACGG }\end{array}$ & 40.4 & 108.6 & 6.7 & 45.3 & 37.2 & 98.5 & 6.7 & 45.8 \\
\hline $\begin{array}{l}\text { GUCAUCA CUG } \\
\text { CAG AGUAGAC }\end{array}$ & 49.3 & 136.9 & 6.8 & 38.7 & 56.2 & 159.6 & 6.7 & 37.7 \\
\hline $\begin{array}{l}\text { GGCAGCGC GCC } \\
\text { CCG CGCGACGG }\end{array}$ & 76.8 & 203.6 & 13.7 & 73.2 & 70.6 & 185.3 & 13.2 & 73.8 \\
\hline $\begin{array}{l}\text { CGCCAGCAC AGCC } \\
\text { GCGG CGUGAUCGG }\end{array}$ & 88.9 & 236.1 & 14.7 & 68.7 & 82.3 & 219.4 & 14.2 & 68.9 \\
\hline $\begin{array}{l}\text { bB } \\
\text { G CAUGAC } \\
\text { CAGUAC G }\end{array}$ & 36.9 & 106.5 & 3.9 & 22.4 & 35.5 & 101.5 & 4.1 & 23.9 \\
\hline $\begin{array}{l}\text { G GUACAC } \\
\text { CACAUG G }\end{array}$ & 38.1 & 106.0 & 5.2 & 33.3 & 38.1 & 105.8 & 5.2 & 33.4 \\
\hline $\begin{array}{l}\text { C GUCGACAG } \\
\text { GACAGCUG C }\end{array}$ & 72.5 & 199.7 & 10.6 & 59.6 & 63.0 & 170.3 & 10.1 & 60.6 \\
\hline $\begin{array}{l}\text { C GGUACCAG } \\
\text { GACCAUGG C }\end{array}$ & 62.7 & 169.7 & 10.1 & 60.4 & 58.1 & 155.8 & 9.8 & 60.9 \\
\hline $\begin{array}{l}\text { C GGUACCAG } \\
\text { GACCAUGG C }\end{array}$ & 52.2 & 137.6 & 9.5 & 61.4 & 51.8 & 135.8 & 9.7 & 63.2 \\
\hline $\begin{array}{l}\text { C GUGCACAG } \\
\text { GACACGUG C }\end{array}$ & 63.7 & 169.7 & 11.1 & 65.7 & 69.7 & 187.4 & 11.6 & 65.7 \\
\hline $\begin{array}{l}\text { CG GCACG } \\
\text { GCACG GC }\end{array}$ & 23.0 & 54.3 & 6.2 & 43.9 & 36.5 & 98.5 & 6.0 & 39.3 \\
\hline $\begin{array}{l}\text { GC ACUACG } \\
\text { CGAUGA GC }\end{array}$ & 52.3 & 152.3 & 5.0 & 28.4 & 50.4 & 145.6 & 5.2 & 29.1 \\
\hline $\begin{array}{l}\text { CG GUACACG } \\
\text { GCACAUG GC }\end{array}$ & 26.3 & 66.3 & 5.8 & 38.2 & 27.9 & 70.9 & 5.9 & 39.3 \\
\hline $\begin{array}{l}\text { GC GGCCAGC } \\
\text { CGACCGG CG }\end{array}$ & 54.7 & 142.2 & 10.6 & 67.4 & 53.3 & 139.3 & 10.2 & 65.3 \\
\hline $\begin{array}{l}\text { GC AGGUGAGC } \\
\text { CGAUCCAC CG }\end{array}$ & 56.2 & 152.1 & 9.0 & 51.3 & 51.9 & 138.6 & 8.9 & 52.0 \\
\hline $\begin{array}{l}\text { GC GUGCACAGC } \\
\text { CGACACGUG CG }\end{array}$ & 64.9 & 174.7 & 10.7 & 63.1 & 65.7 & 176.7 & 10.9 & 63.8 \\
\hline
\end{tabular}


TABLE 2. Continued

\begin{tabular}{|c|c|c|c|c|c|c|c|c|}
\hline \multirow[b]{2}{*}{ Oligomers ${ }^{\mathrm{c}}$} & \multicolumn{4}{|c|}{$\mathrm{T}_{\mathrm{M}}^{-1}$ vs $\log \mathrm{C}_{\mathrm{T}}$ plots } & \multicolumn{4}{|c|}{ Average of curve fits } \\
\hline & $\begin{array}{c}-\Delta \mathrm{H}^{\circ} \\
(\mathrm{kcal} / \mathrm{mol})\end{array}$ & $\begin{array}{c}-\Delta \mathrm{S}^{\circ} \\
(\mathrm{eu})\end{array}$ & $\begin{array}{c}-\Delta \mathrm{G}_{37}^{\mathrm{O}} \\
(\mathrm{kcal} / \mathrm{mol})\end{array}$ & $\begin{array}{l}\mathrm{T}_{M}{ }^{\mathrm{b}} \\
\left({ }^{\circ} \mathrm{C}\right)\end{array}$ & $\begin{array}{c}-\Delta \mathrm{H}^{\circ} \\
(\mathrm{kcal} / \mathrm{mol})\end{array}$ & $\begin{array}{c}-\Delta \mathrm{S}^{\circ} \\
(\mathrm{eu})\end{array}$ & $\begin{array}{c}-\Delta \mathrm{G}_{37}^{\mathrm{o}} \\
(\mathrm{kcal} / \mathrm{mol})\end{array}$ & $\begin{array}{l}\mathrm{T}_{M}{ }^{\mathrm{b}} \\
\left({ }^{\circ} \mathrm{C}\right)\end{array}$ \\
\hline $\begin{array}{l}\text { CAG GACUG } \\
\text { GUCAC GAC }\end{array}$ & 26.1 & 61.8 & 7.0 & 42.1 & 22.0 & 48.2 & 7.0 & 44.3 \\
\hline $\begin{array}{l}\text { GGC CGAGCC } \\
\text { CCGAGC CGG }\end{array}$ & 60.7 & 165.4 & 9.4 & 57.2 & 54.5 & 146.4 & 9.1 & 57.8 \\
\hline $\begin{array}{l}\text { GUG GCACAC } \\
\text { CACACG GUG }\end{array}$ & 52.8 & 140.0 & 9.4 & 60.3 & 52.1 & 137.7 & 9.4 & 60.9 \\
\hline $\begin{array}{l}\text { GUC ACUACUG } \\
\text { CAGAUGA GAC }\end{array}$ & 39.0 & 104.2 & 6.6 & 37.8 & 41.0 & 111.1 & 6.6 & 37.5 \\
\hline $\begin{array}{l}\text { GGC GCGCAGCC } \\
\text { CCGACGCG CGG }\end{array}$ & 79.3 & 208.2 & 14.7 & 76.8 & 77.1 & 202.1 & 14.5 & 76.8 \\
\hline $\begin{array}{l}\text { CGC CAGCACAGCC } \\
\text { GCGAGUCGUG CGG }\end{array}$ & 86.2 & 229.9 & 15.0 & 70.6 & 85.1 & 226.4 & 14.8 & 70.6 \\
\hline $\begin{array}{l}\text { GCC GUGCUGAGCG } \\
\text { CGGACACGAC CGC }\end{array}$ & 85.6 & 227.6 & 15.1 & 71.3 & 85.0 & 225.5 & 15.1 & 71.6 \\
\hline $\begin{array}{l}\text { CGC CACC ACAGCC } \\
\text { GCGAGUGGUG CGG }\end{array}$ & 74.0 & 191.4 & 14.6 & 75.2 & 74.1 & 191.6 & 14.7 & 75.2 \\
\hline
\end{tabular}

leads to a destabilization of the duplex. The extent of the destabilization varies widely from 0.8 to $11.4 \mathrm{kcal} / \mathrm{mol}$. In general we observe a smaller influence for the bulges in smaller duplexes. This is somewhat expected as we have previously shown that the influence of single nucleotide bulge loops is dependent upon non-nearest neighbor interactions (Kent et al. 2014). The relationship to predict the influence of single bulge loops on duplex formation is given in the equation below:

$$
\Delta G_{37(\text { bulge })}^{\circ}=-0.51 \Delta G_{37(\text { stem })}^{\circ}+0.85,
$$

where $\Delta G^{\circ} 37$ (stem) is the less stable stem for group I bulge loops and the second least stable stem for group II and group III bulge loops (Kent et al. 2014). Therefore, smaller, less stable stems minimize the influence of bulge insertion on the thermodynamics of duplex formation.

The current model used by RNAstructure and Mfold to predict the free energy contribution of two single nucleotide bulge loops in a duplex is just the sum of the contributions of the individual bulge contributions. To determine how the presence of a second bulge influences the stability of a duplex, several potential models were examined. The model that gave the best fit of the data is described below.

Since the current model to predict the influence of a single nucleotide bulge (Kent et al. 2014) is dependent upon the stability of the adjacent stems (Equation 1), we determined the stability of each of the three stems gener- ated by the insertion of the two bulge loops into the RNA duplexes listed in Table 2. We then used Equation 1 to predict the influence of two independent bulge insertions. In testing the model, we determined that using the stability of the stem with the second least stability generates a model that predicts the stability of the insertion of two bulges into a duplex with reasonable accuracy (see Discussion).

\section{DISCUSSION}

\section{Phylogenetic analysis of two single nucleotide bulge loops}

A search of the database of naturally occurring RNA structures found that in cases where duplexes contained two bulge loops, the bulges were often in close proximity to each other. In fact, over half of the structures identified in Table 1 are three or fewer base pairs apart. Since bulge loops were found to be located near one another, we were interested in determining how one bulge loop would influence the thermodynamics for insertion of a second bulge loop near the first.

\section{Possible alternate secondary structures}

The oligomers listed in Table 2 are shown as having two single nucleotide bulge loops. However, alternate secondary 
structures for some of these duplexes are possible. The two most problematic types of sequences are as follows: (i) structures with a single base pair at the end of the duplex; (ii) two structures with a single base pair separating the two bulge loops. The first structures could potentially form a duplex with terminal mismatches and a single nucleotide overhang. The influence of terminal mismatches and single nucleotide overhangs has been measured and can be used to predict the stability of these duplexes as though they have formed these secondary structures (Serra and Turner 1995). The average difference between these predicted free energy values and the measured values for the 13 oligomers with this type of sequence is $0.3 \mathrm{kcal} / \mathrm{mol}$ (average deviation $0.7 \mathrm{kcal} / \mathrm{mol}$ ). The average difference, $0.2 \mathrm{kcal} / \mathrm{mol}$ (average deviation 0.9 ) between the measured and the predicted values for these duplexes where the influence of two bulge loops on duplex stability is predicted by Equation 2 is smaller but not statistically different. In addition, the inclusion of these oligomers does not alter the overall model for the influence of two bulge loops on duplex stability (see below). Therefore, we have chosen to include these duplexes in our analysis. The second set of problematic structures has the two bulges separated by a single base pair. If the base pair did not form, the structure would represent a $3 \times 1$ internal loop. Three duplexes in Table 2 have this potential secondary structure. Assuming that these duplexes form a $3 \times 1$ internal loop, the stability of the duplexes can be predicted (Schroeder and Turner 2000). The difference between the measured and these predications are on average $1.6 \mathrm{kcal} / \mathrm{mol}$; however, these duplexes are also not predicted well as duplexes with two bulge loops, the average difference being almost $2.5 \mathrm{kcal} / \mathrm{mol}$. Therefore, we excluded them from further analysis (Equations 1, 2 and Tables 3,4).

\section{Thermodynamic contribution of two single nucleotide bulge loops to duplex formation}

As previously observed for the insertion of a single nucleotide bulge loop into a duplex, the insertion of two bulge loops destabilized all of the duplexes in this study. The extent of the destabilization is generally larger than observed for the insertion of a single bulge loop; and, perhaps not surprisingly, the range of destabilization is also much wider (Blose et al. 2007). Since the identity of the bulges was constant (two adenosine residues), the magnitude and range of destabilization caused by the bulges must be due to non-nearest neighbor influences, as was observed for the insertion of a single bulge loop into a duplex (Blose et al. 2007). The best predictor of the influence of the two bulge loops on duplex stability was deter- mined to be related to the stability of the adjacent stem. Since the two bulges separate the duplex into three stem regions, we examined a number of possible models to provide a predictive model for the stability of duplexes containing two single nucleotide bulge loops. The model that worked the best uses Equation 1 with the $\Delta G_{37(\text { stem) }}^{\circ}$ being the second least stable stem of the three stems in the duplex.

For example, for the sequence 5' GCAGGUCACG/3' CG CCAG GC, the three stems are GC/CG, GGUC/CCAG, and CG/GC with predicted stabilities of $-3.42,-5.52$, and $-2.36 \mathrm{kcal} / \mathrm{mol}$, respectively. Using the second least stable stem $(-3.42 \mathrm{kcal} / \mathrm{mol})$ and Equation 1, the predicted influence of a single bulge loop would be $2.6 \mathrm{kcal} / \mathrm{mol}$. Since there are two bulge loops in the duplex, the influence of both would be predicted to be $5.2 \mathrm{kcal} / \mathrm{mol}$. The measured value for the insertion of the two bulge loops is $6.53 \mathrm{kcal} / \mathrm{mol}$.

Using this model, the influence of two bulge loops on duplex formation is $\sim 1 \mathrm{kcal} / \mathrm{mol}(0.7 \mathrm{kcal} / \mathrm{mol})$ more destabilizing than the predicted influence of the two individual bulge loops (Table 4). Figure 1 displays a graph of the measured influence of the two bulge loops versus the predicted value, assuming there is no interaction between the two bulge loops. The slope of the line is $\sim 1(1.04)\left(R^{2}=0.81\right)$, suggesting that there is a strong correlation between the measured values and the predicted values for the insertion of two single nucleotide bulge loops within the same duplex. The fact that the measured values for the duplexes with two bulge loops are on average $0.72 \mathrm{kcal} / \mathrm{mol}$ less stable than predicted (value of $Y$ intercept) suggests that there is an interaction between the two bulge loops, which leads to a further destabilization of the duplex relative to the predicted values for the insertion of two bulge loops. Interestingly, we examined the influence of the distance between the bulges (as measured by the predicted influence of the two bulges) versus the difference between the measured and predicted value for the insertion of the bulges and found no correlation between these values (data not shown). This indicates that the observed interaction 
TABLE 4. Comparison of models to predict the influence of bulge loops on a duplex ${ }^{\mathrm{a}}$

\begin{tabular}{|c|c|c|c|c|c|}
\hline \multirow[b]{2}{*}{ Oligomer } & \multicolumn{2}{|c|}{$\Delta \mathrm{G}^{\circ} 37$ (bulge) } & \multicolumn{3}{|c|}{$(\mathrm{kcal} / \mathrm{mol})$} \\
\hline & Measured & Predicted $^{\text {b }}$ Eq. 1 & Difference & Predicted $^{\mathrm{C}}$ Eq. 2 & Difference \\
\hline BB & & & & & \\
\hline $\begin{array}{l}\text { GAGUUCAG } \\
\text { C CAAG C }\end{array}$ & 2.15 & 1.7 & 0.45 & 2.4 & -0.25 \\
\hline $\begin{array}{l}\text { GAGCCGAG } \\
\text { C CGGC C }\end{array}$ & 1.97 & 1.7 & 0.27 & 2.4 & -0.43 \\
\hline $\begin{array}{l}\text { CACCGGCAC } \\
\text { G GGCCG G }\end{array}$ & 3.53 & 1.7 & 1.83 & 2.4 & 1.13 \\
\hline 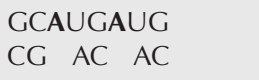 & 2.77 & 3.4 & -0.63 & 4.1 & -1.33 \\
\hline $\begin{array}{l}\text { GUAGGAGC } \\
\text { CA CC CG }\end{array}$ & 4.50 & 5.0 & -0.50 & 5.7 & -1.20 \\
\hline $\begin{array}{l}\text { GCAGCCACG } \\
\text { CG CGG GC }\end{array}$ & 6.99 & 5.2 & 1.79 & 5.9 & 1.09 \\
\hline $\begin{array}{l}\text { GCAGUUCACG } \\
\text { CG CAAG GC }\end{array}$ & 6.53 & 5.2 & 1.33 & 5.9 & 0.63 \\
\hline $\begin{array}{l}\text { GCAGCCGACG } \\
\text { CG CGGC GC }\end{array}$ & 7.11 & 5.2 & 1.91 & 5.9 & 1.21 \\
\hline $\begin{array}{l}\text { GCAUGCGUACG } \\
\text { CG ACGCA GC }\end{array}$ & 8.25 & 5.2 & 3.05 & 5.9 & 2.35 \\
\hline $\begin{array}{l}\text { GGCAUUAGGC } \\
\text { CCG AA CCG }\end{array}$ & 7.79 & 8.5 & -0.71 & 9.2 & -1.41 \\
\hline $\begin{array}{l}\text { GGCAGCAGGC } \\
\text { CCG CG CCG }\end{array}$ & 9.11 & 8.5 & 0.61 & 9.2 & -0.09 \\
\hline $\begin{array}{l}\text { GGCAUAUAGGC } \\
\text { CCG AUA CCG }\end{array}$ & 8.89 & 8.5 & 0.39 & 9.2 & -0.31 \\
\hline $\begin{array}{l}\text { GGCAUUUAGGC } \\
\text { CCG AAA CCG }\end{array}$ & 8.22 & 8.5 & -0.28 & 9.2 & -0.98 \\
\hline $\begin{array}{l}\text { GGCAGGCAGGC } \\
\text { CCG CCG CCG }\end{array}$ & 9.47 & 8.5 & 0.97 & 9.2 & 0.27 \\
\hline $\begin{array}{l}\text { GGCAUUUUAGGC } \\
\text { CCG AAAA CCG }\end{array}$ & 9.55 & 8.5 & 1.05 & 9.2 & 0.35 \\
\hline $\begin{array}{l}\text { GGCAUAAUAGGC } \\
\text { CCG AUUA CCG }\end{array}$ & 9.42 & 8.5 & 0.92 & 9.2 & 0.22 \\
\hline $\begin{array}{l}\text { Bb } \\
\text { GAGUAC C } \\
\text { C CAUGAG }\end{array}$ & 2.21 & 1.7 & 0.51 & 2.4 & -0.19 \\
\hline $\begin{array}{l}\text { GAGGAACC G } \\
\text { C CCUUCCAC }\end{array}$ & 3.27 & 1.7 & 1.57 & 2.4 & 0.87 \\
\hline $\begin{array}{l}\text { CAGUCCAC G } \\
\text { G CAGGUGAC }\end{array}$ & 0.83 & 1.7 & -0.87 & 2.4 & -1.57 \\
\hline $\begin{array}{l}\text { CAGUGCAC G } \\
\text { G CACGUGAC }\end{array}$ & 1.52 & 1.7 & -0.18 & 2.4 & -0.88 \\
\hline $\begin{array}{l}\text { CAGGUACC G } \\
\text { G CCAUGGAC }\end{array}$ & 1.23 & 1.7 & -0.47 & 2.4 & -1.17 \\
\hline $\begin{array}{l}\text { CGAGC CG } \\
\text { GC CGAGC }\end{array}$ & 4.04 & 4.1 & -0.06 & 4.8 & -0.76 \\
\hline
\end{tabular}


TABLE 4. Continued

\begin{tabular}{|c|c|c|c|c|c|}
\hline \multirow[b]{2}{*}{ Oligomer } & \multicolumn{2}{|c|}{$\Delta \mathrm{G}_{37 \text { (bulge) }}^{\circ}$} & \multicolumn{3}{|c|}{ (kcal/mol) } \\
\hline & Measured & Predicted $^{\text {b }}$ Eq. 1 & Difference & Predicted ${ }^{\mathrm{C}}$ Eq. 2 & Difference \\
\hline $\begin{array}{l}\text { CGAUGA GC } \\
\text { GC ACUACG }\end{array}$ & 5.47 & 5.2 & 0.27 & 5.9 & -0.43 \\
\hline $\begin{array}{l}\text { CGAGUAC CG } \\
\text { GC CAUGAGC }\end{array}$ & 6.43 & 4.1 & 2.33 & 4.8 & 1.63 \\
\hline $\begin{array}{l}\text { GCAGGCC GC } \\
\text { CG CCGGACG }\end{array}$ & 6.78 & 5.2 & 1.58 & 5.9 & 0.88 \\
\hline $\begin{array}{l}\text { GUGAGC CAC } \\
\text { CAC CGAGUG }\end{array}$ & 8.02 & 6.1 & 1.92 & 6.8 & 1.22 \\
\hline $\begin{array}{l}\text { GGCACG GCC } \\
\text { CCG GCACGG }\end{array}$ & 11.02 & 8.5 & 2.52 & 9.2 & 1.82 \\
\hline $\begin{array}{l}\text { GUCAUCA CUG } \\
\text { CAG AGUAGAC }\end{array}$ & 6.67 & 6.0 & 0.67 & 6.7 & -0.03 \\
\hline $\begin{array}{l}\text { GGCAGCGC GCC } \\
\text { CCG CGCGACGG }\end{array}$ & 9.06 & 8.5 & 0.56 & 9.2 & -0.14 \\
\hline $\begin{array}{l}\text { CGCCAGCAC AGCC } \\
\text { GCGG CGUGAUCGG }\end{array}$ & 11.25 & 10.2 & 1.05 & 10.9 & 0.35 \\
\hline $\begin{array}{l}\text { bB } \\
\text { G GUACAC } \\
\text { CACAUG G }\end{array}$ & 2.61 & 1.7 & 0.91 & 2.4 & 0.21 \\
\hline $\begin{array}{l}\text { G CAUGAC } \\
\text { CAGUAC G }\end{array}$ & 3.74 & 1.7 & 2.04 & 2.4 & 1.34 \\
\hline $\begin{array}{l}\text { C GUCGACAG } \\
\text { GACAGCUG C }\end{array}$ & 1.14 & 1.7 & -0.56 & 2.4 & 1.26 \\
\hline $\begin{array}{l}\text { C GGUACCAG } \\
\text { GACCAUGG C }\end{array}$ & 2.43 & 1.7 & 0.73 & 2.4 & 0.03 \\
\hline $\begin{array}{l}\text { C GGUACCAG } \\
\text { GACCAUGG C }\end{array}$ & 3.03 & 1.7 & 1.33 & 2.4 & 0.63 \\
\hline $\begin{array}{l}\text { C GUGCACAG } \\
\text { GACACGUG C }\end{array}$ & 1.22 & 1.7 & -0.48 & 2.4 & -1.18 \\
\hline $\begin{array}{l}\text { CG GCACG } \\
\text { GCACG GC }\end{array}$ & 3.94 & 4.1 & -0.16 & 4.8 & -0.86 \\
\hline $\begin{array}{l}\text { GC ACUACG } \\
\text { CGAUGA GC }\end{array}$ & 5.47 & 5.2 & 0.27 & 5.9 & -0.43 \\
\hline $\begin{array}{l}\text { GC GGCCAGC } \\
\text { CGACCGG CG }\end{array}$ & 6.78 & 5.2 & 1.58 & 5.9 & 0.88 \\
\hline $\begin{array}{l}\text { CG GUACACG } \\
\text { GCACAUG GC }\end{array}$ & 6.73 & 5.2 & 1.53 & 5.9 & 0.83 \\
\hline $\begin{array}{l}\text { GC GGCCAGC } \\
\text { CGACCGG CG }\end{array}$ & 6.38 & 5.2 & 1.18 & 5.9 & 0.48 \\
\hline $\begin{array}{l}\text { GC AGGUGAGC } \\
\text { CGAUCCAC CG }\end{array}$ & 8.81 & 5.2 & 3.61 & 5.9 & 2.91 \\
\hline $\begin{array}{l}\text { GC GUGCACAGC } \\
\text { CGACACGUG CG }\end{array}$ & 8.46 & 5.2 & 3.26 & 5.9 & 2.56 \\
\hline $\begin{array}{l}\text { GGC CGAGCC } \\
\text { CCGAGC CGG }\end{array}$ & 8.32 & 8.5 & -0.18 & 9.2 & -0.88 \\
\hline $\begin{array}{l}\text { GUG GCACAC } \\
\text { CACACG GUG }\end{array}$ & 4.72 & 6.1 & -1.38 & 6.8 & -2.08 \\
\hline
\end{tabular}


TABLE 4. Continued

\begin{tabular}{|c|c|c|c|c|c|}
\hline \multirow[b]{2}{*}{ Oligomer } & \multicolumn{2}{|c|}{$\Delta \mathrm{G}^{\circ} 3$ (bulge) } & \multicolumn{3}{|c|}{$(\mathrm{kcal} / \mathrm{mol})$} \\
\hline & Measured & Predicted $^{\mathrm{b}}$ Eq. 1 & Difference & Predicted $^{\mathrm{C}}$ Eq. 2 & Difference \\
\hline $\begin{array}{l}\text { GUC ACUACUG } \\
\text { CAGAUGA GAC }\end{array}$ & 6.87 & 6.0 & 0.87 & 6.7 & 0.17 \\
\hline $\begin{array}{l}\text { GGC GCGCAGCC } \\
\text { CCGACGCG CGG }\end{array}$ & 8.06 & 8.5 & -0.44 & 9.2 & -1.14 \\
\hline $\begin{array}{l}\text { CGC CAGCACAGCC } \\
\text { GCGAGUCGUG CGG }\end{array}$ & 10.95 & 8.5 & 2.45 & 9.2 & 1.75 \\
\hline $\begin{array}{l}\text { GCC GUGCUGAGCG } \\
\text { CGGACACGAC CGC }\end{array}$ & 7.85 & 8.5 & -0.66 & 9.2 & -1.36 \\
\hline $\begin{array}{l}\text { CGC CACCACA GCC } \\
\text { GCGAGUGGUG CGG }\end{array}$ & 11.35 & 8.5 & 2.85 & 9.2 & 2.15 \\
\hline $\begin{array}{l}\text { Average difference } \\
\text { Average deviation }\end{array}$ & & & $\begin{array}{l}0.65 \\
1.3\end{array}$ & & $\begin{array}{l}0.15 \\
1.0\end{array}$ \\
\hline
\end{tabular}

of the two bulges is no greater when the bulges are inserted near each other ( $1 \mathrm{bp}$ away) or further (up to $6 \mathrm{bp}$ away), nor is the orientation of the bulge relative to each other (BB, Bb, or bB) important. Thus we can use the current model for the prediction of the influence of a single bulge loop to predict the influence of two bulge loops into a single duplex. The model is given below:

$$
\begin{aligned}
& \Delta G_{37 \text { (for insertion of two bulge loops) }}^{\circ} \\
& \quad=2 \times\left(-0.51 \Delta G_{37 \text { (stem) }}^{\circ}+0.85\right)+0.72
\end{aligned}
$$

where $\Delta G^{\mathrm{o}} 37$ (stem) is the second least stable stem of the three stems. This model should improve the prediction

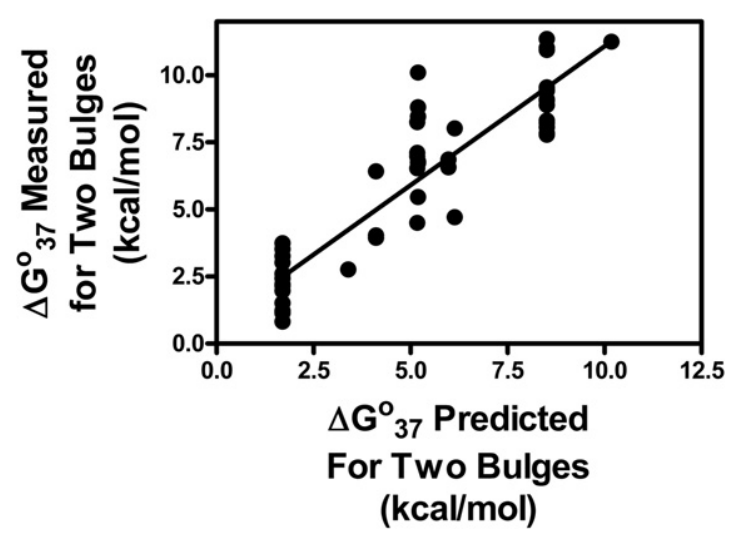

FIGURE 1. Plot of measured free energy change for the insertion of two single Group I nucleotide bulge loops into a duplex, $\Delta G^{\mathrm{o}}$ 37bulges, versus predicted free energy value for the insertion of noninteracting two single nucleotide bulge loops (Equation 1) into a duplex as described in text. Line is the least-squares fit of the data points. of RNA secondary structure and RNA stability from sequence.

Table 4 lists the measured free energy values for the insertion of two bulge loops into a duplex and the predicted values using Equation 1 (no interaction between the two bulge loops) and Equation 2 (includes the additional $0.7 \mathrm{kcal} / \mathrm{mol}$ interaction between the two bulge loops). The addition of the $0.7 \mathrm{kcal} / \mathrm{mol}$ interaction improves the prediction for almost two-thirds (32 of 50 duplexes) of the duplexes in Table 4 . The average difference between the measured and predicted free energy value using Equation 2 is $0.15 \mathrm{kcal} /$ mol. The average deviation between the measured and predicted free energy value for the insertion of two bulge loops into an RNA duplex using Equation 2 is $1.0 \mathrm{kcal} / \mathrm{mol}$ which is twice the value we measured for the insertion of a single bulge into an RNA duplex (Znosko et al. 2002). Twentyeight of the 50 duplexes $(56 \%)$ are predicted within $1 \mathrm{kcal} /$ $\mathrm{mol}$ or $0.5 \mathrm{kcal} / \mathrm{mol}$ per inserted bulge and another 17 are predicted within $2 \mathrm{kcal} / \mathrm{mol}$ of the measured value. The remaining five oligomers (10\%) have a predicted value that is more than $2 \mathrm{kcal} / \mathrm{mol}$ greater than the measured value. While this seems a large difference, five of the 37 oligomers (14\%) with a single nucleotide bulge loop had a measured and predicted value that differed by more than $0.75 \mathrm{kcal} /$ mol (Znosko et al. 2002). An examination of the oligomers in Table 4, which were poorly predicted, does not reveal any obvious structural feature that would explain the differences between the measured and predicted free energy values. Non-nearest neighbor interactions cannot be easily incorporated into current free energy prediction models (Mathews and Turner 2002) and may require an iterative process to arrive at a free energy value of an RNA containing a bulge loop. 


\section{Structural analysis of naturally occurring double nucleotide bulge loops}

RNA FRABASE was used to search for three-dimensional structures of duplexes containing two bulge loops separated by up to $10 \mathrm{bp}$ (Popenda et al. 2010). A total of 27 unique examples were identified (Ye et al. 1995; Carter et al. 2000; Ben-Shem et al. 2001, 2011; Berglund et al. 2001; Merianos et al. 2004; Berk et al. 2006; Walden et al. 2006; Weixlbaumer et al. 2008; Blaha et al. 2009; Agirrezabala et al. 2010; Armache et al. 2010; Bulkley et al. 2010; Jenner et al. 2010; Jin et al. 2010; Hainzl et al. 2011; Ng et al. 2011; Rabl et al. 2011; Demeshkina et al. 2012; Anger et al. 2013; Hashem et al. 2013; Amunts et al. 2014; Gogala et al. 2014). The secondary and tertiary structures of the duplexes are presented in the Supplemental Material. All of the bulge loop structures display a structure previously identified (Znosko et al. 2002). Of the 54 bulged nucleotides, 24 are intercalated, 27 are extrahelical, and three form base triples. In most of the examples, the bulged nucleotides have no discernible tertiary structural interactions. In four of the 27 structures, the bulge loop nucleotides are involved in tertiary interactions; these are displayed in Figure 2. The first example (panel A) is the only structure where the two bulged nucleotides appear to interact. In this case, the two bulged adenosines (1260 and 1275) on opposite strands are stacked. This leads to continuous stacking of C1262, A1261, A1275, and G1276. There are three examples where the bulged nucleotide is interacting with other residues. In panel $\mathrm{B}$, the bulged U10 is stacked on adenosine residue 28 and forms a base triple with A13 and U24. In panel C, the bulged A5 is paired with G15 of a second molecule in the unit cell. In panel D, the bulged G (926) is stacked on a G residue at position 1505.

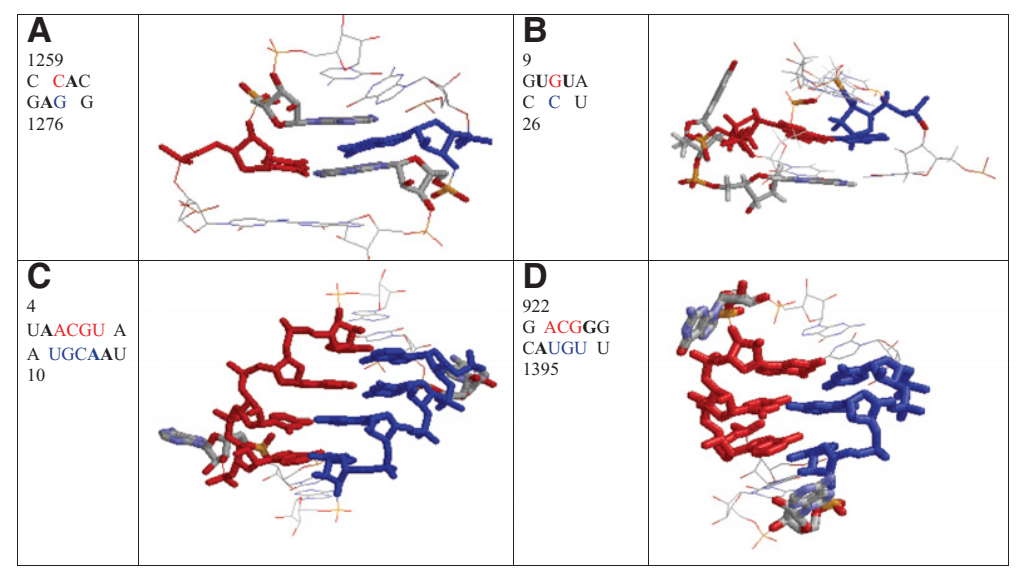

FIGURE 2. Secondary structure diagrams (left panel) and three-dimensional presentations (right panel) are shown. The bulged nucleotide is shown in CPK color and the intervening nearest neighbor pairs in red (top strand) and blue (bottom strand). (A) Position 1259 of the T. thermophilus small subunit rRNA. (B) Position 9 Bovine TAT-TAR complex. (C) Position 4 model U2snRNA branchpoint duplex. (D) Position 922 of the T. thermophilus small subunit rRNA. Extracted from pdb files: 3UZ7, 1BIV, 1I9X, and 3IZ9.
These examples emphasize the structural flexibility imparted into the RNA when bulges are introduced. Further investigation will be needed to understand the forces responsible for the selection of the correct bulged nucleotide and its orientation in a complex structural motif.

\section{MATERIALS AND METHODS}

\section{RNA synthesis and purification}

Oligomers were synthesized on CPG solid supports (Applied Biosystems 392 DNA/RNA Synthesizer) utilizing phosphoramidites with the $2^{\prime}$ hydroxyl protected as the tert-butyl dimethylsilyl ether from Glen Research. Oligomers underwent ammonia and fluoride deprotection, and a crude sample was purified using preparative tlc (n-propanol:ammonium hydroxide:water, 55:35:10) and SepPak C18 (Waters) chromatography as previously described (Serra et al. 1994). Sample purity was determined through analytical tlc or HPLC (C-8) and was $>95 \%$.

\section{Melting curve and data analysis}

Optical melting experiments were performed as previously described in $1 \mathrm{M} \mathrm{NaCl}$ melt buffer $(1 \mathrm{M} \mathrm{NaCl}, 0.02 \mathrm{M}$ cacodylic acid, 0.001 M EDTA, pH 7.0) (Serra et al. 1994). Absorbance versus temperature profiles were fit to a two-state model with sloping base lines using a nonlinear least squares program, Meltwin (McDowell and Turner 1996). Thermodynamic parameters for duplex formation were obtained as previously described (McCann et al. 2011).

\section{Determination of the contribution of bulge loops to duplex thermodynamics}

The free energy of duplex formation can be approximated by the nearest-neighbor model (Xia et al. 2001). The free energy contribution of the bulged nucleotides was calculated from the experimental data and the nearest neighbor model according to Equation 3,

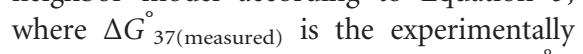
determined value from the melts and $\Delta G_{37}^{\circ}$ (duplex) is calculated from the nearest-neighbor model for the duplex as if it did not contain the bulges.

$$
\begin{aligned}
\Delta G_{37 \text { (bulges })}^{\circ} & \Delta G_{37 \text { (measured })}^{\circ} \\
& -\Delta G_{37 \text { (duplex). }}^{\circ}
\end{aligned}
$$

\section{Phylogenetic analysis}

A database of phylogenetically determined RNA secondary structures of 305 small subunit rRNAs, 169 large subunnit rRNAs, 16 Group I RNAs, and seven Group II RNAs, was searched for duplexes containing two single nucleotide bulge loops (Andronescu et al. 2008). The loops were characterized by relative position within the duplex. 


\section{SUPPLEMENTAL MATERIAL}

Supplemental material is available for this article.

\section{ACKNOWLEDGMENTS}

This work was supported by National Science Foundation grant no. MCB-1410239 and The Paul E. and Mildred L. Hill Fund of Allegheny College.

Received January 29, 2016; accepted November 13, 2016.

\section{REFERENCES}

Agirrezabala X, Liao HY, Schreiner E, Fu J, Ortiz-Meoz RF, Schulten K, Green R, Frank J. 2010. Structural characterization of mRNA-tRNA translocation intermediates. Proc Natl Acad Sci 109: 6094-6099.

Ahlquist P. 2002. RNA-dependent RNA polymerases, viruses, and RNA silencing. Science 296: 1270-1273.

Allawi HT, SantaLucia J Jr. 1997. Thermodynamics and NMR of internal G.T mismatches in DNA. Biochemistry 36: 10581-10594.

Altman S. 1990. Ribonuclease P. Postscript. J Biol Chem 265: 20053-20056.

Amunts A, Brown A, Bai XC, Llacer JL, Hussain T, Emsley P, Long F, Murshudov G, Scheres S, Ramakrishnan V. 2014. Structure of the yeast mitochondrial large ribosomal subunit. Science 343: 1485-1489.

Andronescu M, Condon A, Hoos HH, Mathews DH, Murphry KP. 2007. Efficient parameter estimation for RNA secondary structure prediction. Bioinformatics 23: i19-i28.

Andronescu M, Bereg V, Hoos HH, Condon A. 2008. RNA STRAND: the RNA secondary structure and statistical analysis database. BMC Bioinformatics 9: 340 .

Anger AM, Armache JP, Berninghausen O, Habeck M, Subklewe M, Wilson DN, Beckmann R. 2013. Structures of the human and Drosophila 80S ribosome. Nature 497: 80-85.

Armache JP, Jarasch A, Anger AM, Villa E, Becker T, Bhushan S, Jossinet F, Habeck M, Dindar G, Franckenberg S, et al. 2010. Cryo-EM structure and rRNA model of a translating eukaryotic 80 S ribosome at 5.5- $\AA$ resolution. Proc Natl Acad Sci 107: 19748-19753.

Ben-Shem A, Garreau de Loubress N, Melnikov S, Jenner L, Yusupova G, Yusupov M. 2001. The structure of the eukaryotic ribosome at $3.0 \AA$ resolution. Science 334: 1524-1529.

Ben-Shem A, Jenner L, Yusupova G, Yusupov M. 2011. Crystal structure of the eukaryotic ribosome. Science 330: 1203-1209.

Berglund JA, Rosbash M, Schultz SC. 2001. Crystal structure of a model branchpoint-U2 snRNA duplex containing bulged adenosines. RNA 7: 682-691.

Berk V, Zhang W, Pai RD, Cate JHD. 2006. Structural basis for mRNA and tRNA positioning on the ribosome. Proc Natl Acad Sci 103: $15830-15834$

Blaha G, Stanley RE, Steitz TA. 2009. Formation of the first peptide bond: the structure of EF-P bound to the $70 \mathrm{~S}$ ribosome. Science 325: 966-970.

Blose JM, Manni ML, Klapec KA, Stranger-Jones Y, Zyra AC, Sim V, Griffith CA, Long JD, Serra MJ. 2007. Non-nearest-neighbor dependence of the stability for RNA bulge loops based on the complete set of group I single-nucleotide bulge loops. Biochemistry 46: 15123-15135.

Bulkley D, Innis CA, Blaha G, Steitz TA. 2010. Revisiting the structures of several antibiotics bound to the bacterial ribosome. Proc Natl Acad Sci 107: 17158-17163.

Carter AP, Clemons WM Jr, Brodersen DE, Morgan-Warren RJ, Wimberly BT, Ramakrishnan V. 2000. Functional insights from the structure of the $30 \mathrm{~S}$ ribosomal subunit and its interactions with antibiotics. Nature 407: 340-348.

Cech TR. 1990. Self splicing of group I introns. Annu Rev Biochem 59: 543-568.

Chan JH, Lim S, Wong WS. 2006. Antisense oligonucleotides: from design to therapeutic application. Clin Exp Pharmacol Physiol 33: 533-540.

Chen JL, Dishler AL, Kennedy SD, Yildirim I, Liu B, Turner DH, Serra MJ. 2012. Testing the nearest neighbor model for canonical RNA base pairs: revision of GU parameters. Biochemistry 51: 3508-3522.

Climie SC, Friesen JD. 1987. Feedback regulation of the rplJL-rpoBC ribosomal protein operon of Escherichia coli requires a region of mRNA secondary structure. J Mol Biol 198: 371-381.

Demeshkina N, Jenner L, Westhof E, Yusupov M, Yusupova G. 2012. A new understanding of the decoding principle on the ribosome. Nature 484: 256-259.

Fink TR, Crothers DM. 1972. Free energy of imperfect nucleic acid helices. I. The bulge defect. J Mol Biol 66: 1-12.

Freier SM, Kierzek R, Jaeger J, Sugimoto N, Caruthers MH, Neilson T, Turner DH. 1986. Improved free-energy parameters for predictions of RNA duplex stability. Proc Natl Acad Sci 83: 9373-9377.

Gogala M, Becker T, Beatrix B, Armache JP, Barrio-Garcia C, Berninghausen O, Beckmann R. 2014. Structures of the Sec61 complex engaged in nascent peptide translocation or membrane insertion. Nature 506: 107-110.

Groebe DR, Uhlenbeck OC. 1988. Characterization of RNA hairpin loop stability. Nucleic Acids Res 16: 11725-11735.

Gutell RR, Cannone JJ, Shang Z, Du Y, Serra MJ. 2000. A story: unpaired adenosine bases in ribosomal RNAs. J Mol Biol 304: 335-354.

Guttman M, Amit I, Garber M, French C, Lin MF, Feldser D, Huarte M, Zuk O, Carey BW, Cassady JP, et al. 2009. Chromatin signature reveals over a thousand highly conserved large non-coding RNAs in mammals. Nature 458: 223-227.

Hainzl T, Huang S, Merilainen G, Brannstrom K, Sauer-Eriksson AE. 2011. Structural basis of signal-sequence recognition by the signal recognition particle. Nat Struct Mol Biol 18: 389-391.

Harper JW, Logsdon NJ. 1991. Refolded HIV-1 tat protein protects both bulge and loop nucleotides in TAR RNA from ribonucleolytic cleavage. Biochemistry 30: 8060-8066.

Hashem Y, Des Georges A, Fu J, Buss SN, Jossinet F, Jobe A, Zhang Q, Liao HY, Grassucci RA, Bajaj C, et al. 2013. High-resolution cryoelectron microscopy structure of the Trypanosoma brucei ribosome. Nature 494: 385-389.

Jenner LB, Demeshkina N, Yusupov G, Yusupo M. 2010. Structural aspects of messenger RNA reading frame maintenance by the ribosome. Nat Struct Mol Biol 17: 555-560.

Jin H, Kelley AC, Loakes D, Ramakrishnan V. 2010. Structure of the 70S ribosome bound to release factor 2 and a substrate analog provides insights into catalysis of peptide release. Proc Natl Acad Sci 107: 8593-8598.

Kent JL, McCann MD, Phillips D, Panaro BL, Lim GFS, Serra MJ. 2014. Non-nearest-neighbor dependence of stability for group III RNA single nucleotide bulge loops. RNA 20: 825-834.

Lilley DM. 1995. Kinking of DNA and RNA by base bulges. Proc Natl Acad Sci 92: 7140-7152.

Lim GFS, Merz GE, McCann MD, Gruskiewicz JM, Serra MJ. 2012. Stability of single nucleotide bulge loops embedded in an RNA hairpin stem. RNA 18: 807-814.

Longfellow CE, Kierzek R, Turner DH. 1990. Thermodynamic and spectroscopic study of bulge loops in oligoribonucleotides. Biochemistry 29: 278-285.

Lu ZJ, Gloor JW, Mathews DH. 2009. Improved RNA secondary structure prediction by maximizing expected pair accuracy. RNA 15: 1805-1813.

Mathews DH, Sabina J, Zuker M, Turner DH. 1999. Expanded sequence dependence of thermodynamic parameters provides improved prediction of RNA secondary structure. J Mol Biol 288: 911-940. 
Mathews DH, Turner DH. 2002. Dynalign: an algorithm for finding the secondary structure common to two RNA sequences. J Mol Biol 317: 191-203.

McCann MD, Lim GFS, Manni ML, Estes J, Klapec KA, Frattini GD, Knarr RJ, Gratton JL, Serra MJ. 2011. Non-nearest-neighbor dependence of the stability for RNA group II single nucleotide bulge loops. RNA 17: 108-119.

McDowell JA, Turner DH. 1996. Investigation of the structural basis for thermodynamic stabilities of tandem GU mismatches: solution structure of (rGAGGUCUC) ${ }_{2}$ by two-dimensional NMR and simulated annealing. Biochemistry 35: 14077-14089.

Merianos HJ, Wang J, Moore PB. 2004. The structure of a ribosomal protein S8/spc operon mRNA complex. RNA 10: 954-964.

Michel F, Dujon B. 1983. Conservation of RNA secondary structures in two intron families including mitochondrial-, chloroplast- and nuclear-encoded members. EMBO J 2: 33-38.

Ng CL, Lang K, Meenan NAG, Sharma A, Kelley AC, Kleanthous C, Ramakrishnan V. 2011. Structural basis for 16 S ribosomal RNA cleavage by the cytotoxic domain of colicin E3. Nat Struct Mol Biol 17: 1241-1246.

Nissen P, Hansen J, Ban N, Moore PB, Steitz TA. 2000. The structural basis of ribosomal activity in peptide bond synthesis. Science 289: 920-930.

Noller HF, Hoffarth V, Zimmiak L. 1992. Unusual resistance of peptidyl transferase to protein extraction. Science 265: 3587-3590.

Pace NR, Brown JW. 1995. Evolutionary perspective on the structure and function of ribonuclease P, a ribozyme. J. Bacteriol 177: 1919-1928.

Parker R, Siliciano PG, Guthrie C. 1987. Recognition of the TACTAAC box during mRNA splicing in yeast involves base pairing to the U2like snRNA. Cell 49: 229-239.

Peattie DA, Douthwaite S, Garrett RA, Noller HF. 1981. A "bulged” double helix in a RNA-protein contact site. Proc Natl Acad Sci 78: 7331-7335.

Plasterk RHA. 2002. RNA silencing: the genome's immune system. Science 296: 1263-1265.

Popenda M, Szachniuk M, Blazewicz M, Wasik S, Burke EK, Blazewicz J, Adamia RW. 2010. RNA FRABASE 2.0: an advanced web-accessible database with the capacity to search the three-dimensional fragments within RNA structures. BMC Bioinformatics 11: 231.

Rabl J, Leibundgut M, Ataide SF, Haag A, Ban N. 2011. Crystal structure of the eukaryotic $40 \mathrm{~S}$ ribosomal subunit in complex with initiation factor 1. Science 331: 730-736.
Rinn JL, Chang HY. 2012. Genome regulation by long noncoding RNAs. Ann Rev Biochem 81: 145-166.

Roth A, Breaker RR. 2009. The structural and functional diversity of metabolite-binding riboswitches. Ann Rev Biochem 78: 305-334.

Schmelzer C, Schweyen RJ. 1986. Self-splicing of group II introns in vitro: mapping of the branch point and mutational inhibition of lariat formation. Cell 46: 557-565.

Schroeder SJ, Turner DH. 2000. Factors affecting the thermodynamics stability of small asymmetric internal loops in RNA. Biochemistry 39: 9257-9274.

Scott WG. 2007. Ribozymes. Curr Opin Struct Biol 17: 280-286.

Serra MJ, Turner DH. 1995. Predicting thermodynamic properties of RNA. Methods Enzymol 259: 242-261.

Serra MJ, Axenson TJ, Turner DH. 1994. A model for the stabilities of RNA hairpins based on a study of the sequence dependence of stability for hairpins of six nucleotides. Biochemistry 33: 14289-14296.

Turner DH, Sugimoto N, Freier SM. 1988. RNA structure prediction. Ann Rev Biophys Chem 17: 167-192.

Uhlman E, Peyman A. 1990. Antisense oligonucleotides: a new therapeutic principle. Chem Rev 90: 543-584.

Walden WE, Selezneva AI, Dupuy J, Volbeda A, Fontecilla-Camps JC, Theil EC, Volz K. 2006. Structure of dual function iron regulatory protein 1 complexed with ferritin IRE-RNA. Science 314: 1903-1908.

Weixlbaumer A, Jin H, Neubauer C, Voorhees RM, Petry S, Kelley C, Ramakrishnan V. 2008. Insights into translational termination from the structure of RF2 bound to the ribosome. Science 322: 953-956.

Winkler WC, Nahvi A, Roth A, Collins JA, Breaker RR. 2004. Control of gene expression by a natural metabolite-responsive ribozyme. Nature 428: 281-286.

Woese CR, Gutell RR. 1989. Evidence for several higher order structural elements in ribosomal RNA. Proc Natl Acad Sci 86: 3119-3122.

Wu HN, Uhlenbeck OC. 1987. Role of a bulged A residue in a specific RNA-protein interaction. Biochemistry 26: 8221-8227.

Xia T, Mathews DH, Turner DH. 2001. Thermodynamics of RNA secondary structure formation in RNA (ed. Soll DG, et al.), pp. 21-48. Elsevier, New York, NY.

Ye X, Kumar RA, Patel DJ. 1995. Molecular recognition in the bovine immunodeficiency virus Tat peptide-TAR RNA complex. Chem Biol 2: 827-840.

Znosko BM, Silvestri SB, Volkman H, Boswell B, Serra MJ. 2002. Thermodynamic parameters for an expanded nearest-neighbor model for the formation of RNA duplexes with single nucleotide bulges. Biochemistry 41: 10406-10417. 

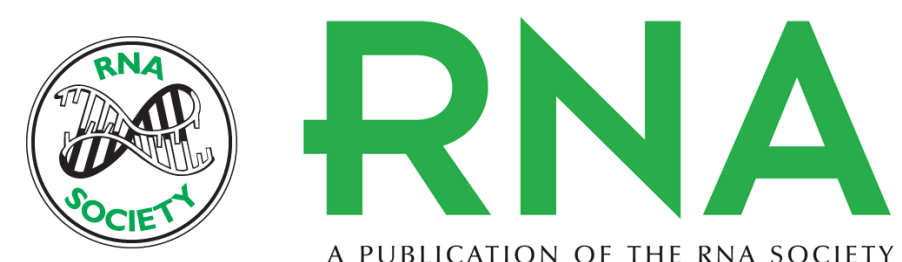

A PUBLICATION OF THE RNA SOCIETY

\section{Influence of two bulge loops on the stability of RNA duplexes}

Claire V. Crowther, Laura E. Jones, Jessica N. Morelli, et al.

RNA 2017 23: 217-228 originally published online November 21, 2016

Access the most recent version at doi:10.1261/rna.056168.116

Supplemental Material

References

Creative Commons License

Email Alerting Service
http://rnajournal.cshlp.org/content/suppl/2016/11/21/rna.056168.116.DC1

This article cites 69 articles, 24 of which can be accessed free at: http://rnajournal.cshlp.org/content/23/2/217.full.html\#ref-list-1

This article is distributed exclusively by the RNA Society for the first 12 months after the full-issue publication date (see http://rnajournal.cshlp.org/site/misc/terms.xhtml). After 12 months, it is available under a Creative Commons License (Attribution-NonCommercial 4.0 International), as described at http://creativecommons.org/licenses/by-nc/4.0/.

Receive free email alerts when new articles cite this article - sign up in the box at the top right corner of the article or click here.

To subscribe to $R N A$ go to:

http://rnajournal.cshlp.org/subscriptions 